\title{
Classification of the Parts of Speech in Arabic
} A Discussion on Origins, Theories, and Definitions

\author{
Simona Olivieri \\ Seminar für Semitistik und Arabistik, Freie Universität Berlin, Berlin, Germany \\ simona.olivieri@fu-berlin.de
}

\begin{abstract}
In the Arabic linguistic tradition, the classification of the parts of speech (ism 'noun', fil 'verb', harf 'particle') is first introduced by Sibawayhi, who presents the three key elements in his Kitāb (I:1). The section at issue includes the presentation of the elements but does not provide much in terms of grammatical explanation. Nouns are in fact not introduced with their grammatical characteristics, but rather with examples: fa-l-ism: rağul, wa-faras, wa-ḥāiț ("and the noun is 'man', and 'horse', and 'wall'”) (Kitāb I:1). In addition to nouns, verbs and particles, Arabic grammar further recognized a number of other categories that are not considered as parts of speech but rather fall into the main three. This contribution aims to present relevant classifications of the parts of speech in the Greek and Arabic traditions, with the aim to account for possible external influences on the Arabic formulations, and foster further discussion on the development of the Arabic grammatical disciplines.
\end{abstract}

\section{Keywords}

Arabic - Greek - Arabic linguistic tradition - parts of speech - noun

\section{Introduction and Preliminary Assumptions ${ }^{1}$}

The Kitāb Sibawayhi (8th century), the earliest known treatise on Arabic grammar, introduces most if not all aspects of the discipline. Across the linguistic

1 An earlier draft of this paper was presented at the Colloque International « Parties du Discours » (INALCO, Paris, February 12-13, 2020). I wish to thank the participants in the conference for 
tradition, Sỉbawayhi (d. 180/796?) is considered a most authoritative figure and his legacy is of utmost importance for coeval as well as later grammarians.

However, the origins of Sībawayhi's assertions are vague and, in general, it is difficult to assess the diverse influences that may have played a role in the development of his linguistic theorizations.

As we have discussed in another paper, the technical lexicon presented in the Kitāb seems "to represent a fully-fledged system, based on a well-structured schema. Despite the fact that Sỉbawayhi does not provide clear technical definitions of the terminology used, the technical meaning is instead inferred from the application of the same term in a number of examples provided" (Olivieri 2020, 6).

While Olivieri (2020) addresses a specific case of the specialized lexicon, namely the 'ir $\bar{r} \bar{b} b$, in this paper we will discuss the topic of the parts of speech, taking the category of nouns as a case in point, ${ }^{2}$ more in general terms and as per it is treated in the Arabic linguistic tradition. The ultimate aim is to present a reading of the matter in the light of possible connections with traditions like the Greek that address the topic in similar ways. Finally, the objective is to foster a discussion on the possible extent of such connections, and inquiring if and to what extent Sībawayhi and other Arabic grammarians might have been influenced by other traditions.

\subsection{Previous Studies}

Modern scholarship has dealt with the origins of Arabic grammatical and linguistic studies ${ }^{3}$ from different perspectives, so that for instance Carter discusses influences from other Islamic sciences, focusing in particular on the legal studies (Carter 1972; 2001). Further to this, he also discusses a possible influence of the nahwiyyün, 'grammarians' (cf. Carter 1972, 76), which would be more evident in the introductory part to the Kitāa. On the latter, a thorough discussion is in the paper by Talmon "Naḥwiyyūn in Sïbawayhi's Kitāb" (1982). The paper deals with the general profile of these grammarians, in the light of the fact that:

their comments. I also express my sincere gratitude to Prof. Shabo Talay and to the anonymous reviewers for the valuable remarks.

2 For a comprehensive discussion on the theory of the parts of speech, see Guillaume (1988), in which the author provides a thorough description of the elaboration of the theory as well as of its development in the Arabic linguistic tradition. On this, see also Viain (2017).

3 For a comprehensive history of the Arabic linguistic tradition, see Bohas, Guillaume, and Kouloughli (1990). 
Scholars concerned with the beginnings of Arabic grammatical science who wish to utilize the Kitāb as the basis for a new theory encounter considerable difficulty due to paucity of reliable and contemporary sources dealing with this subject. Ideally, such sources would throw light on the state of scientific thought on the Arabic language both previous to sīBAWAYHI and outside of his scholarly circle, allowing the modern scholar to gauge more accurately both sīBAWAYHI's originality and the extent to which material found in the Kitāb may have been common to others having a scientific interest in the Arabic language. (Talmon 1982, 13)

Talmon, thus, addresses the issue of the - perhaps external - figures that may have played a role in the emergence of the Arabic linguistic and grammatical tradition, reflecting on the scarcity of evidences to assess the matter. However, he ultimately concludes that there must have been an influence on Sïbawayhi. Therefore, his interpretation that "Sībawayhi founded his grammatical system on the groundwork of a fairly advanced school of Grammar!" (Talmon 1982, 29) is of utmost relevance to our considerations, inasmuch as the questions brought up in this paper, as well as in the discussion on the grammatical schools preceding Sībawayhi, ${ }^{4}$ pose a major point in the general approach to Sïbawayhi's Kitāb, namely possible previous or coeval influences. ${ }^{5}$ Ultimately, a reasonable consideration on these questions is that we cannot be absolutely sure of who such figures may have been, and, if they ever played a role in Sībawayhi's theorizations, to what extent this may have contributed to his propositions on the whole.

4 A substantial contribution on this is Talmon's "Eighth-Century Iraqi Grammar: A Critical Exploration of Pre-Halilian Arabic Linguistics" (2003), in which the author tackles some controversial issues of the early stages of the Arabic grammatical tradition, namely the grammatical teaching of al-Halil and Sỉbawayhi, largely adopted by later scholars, and the possibly external - linguistic sources adopted by the grammarians. Accounting for "possibly significant pre-Halilian elements of grammatical theory" (2003, 41), Talmon discusses how the teaching of al-Halil and Sibawayhi may be distinct from the mainstream of grammatical theory up to their time, namely from the tradition of the 'the Old Iraqi School of Grammar' (cf. also Talmon 200o). Thus, his extensive textual analysis of the contribution of earlier (i.e., the formative period of grammar before al-Halīl and Sỉbawayhi) as well as coeval grammarians is first aimed at determining how Sībawayhi's Kitāb may represent an innovative approach to grammatical study, but also describes how other actors may have played a role in, or influenced, the formulation of the early grammatical theories.

5 On this, especially with regard to the possible Syriac influences on Sībawayhi, see Talmon (2008), in which the author points "out briefly several selected topics which seem to have infiltrated from Syriac grammar into the teaching of these early Arab grammarians" (Talmon 2008, 174). 
Another viewpoint on the development of the Arabic linguistic disciplines is that expressed by Versteegh, who discusses how the Greek tradition may have played a role in the development of the Arabic linguistic tradition. ${ }^{6}$ In the long-standing discussion on the origins of Arabic grammar, as a preliminary assumption, this paper will mostly draw on the arguments advanced by Versteegh on the development of grammatical sciences (Versteegh 1977; 1993) as possibly influenced by other traditions. ${ }^{7}$ In our view, both Talmon's conclusions and Versteegh's propositions may well be considered as an ensemble. It is true that Talmon in other papers $(1985 ; 2000)$ mostly discusses of the Medinean and Iraqi centers, which may have contributed to Sībawayhi's theorizations (although in the latter paper, in particular, he also presents possible connections with the Greek tradition). However, the evidence is so scarce that a broader view on the figures may still be considered for further investigation. Albeit such influences may well not be external to the Arabic tradition, we cannot in principle rule out possible external elements that might have played a role in the formulation of Sībawayhi's arguments.

On the other hand, the issue of reconstruction a possible historiographical transmission ${ }^{8}$ of, specifically, Greek notions is also to be considered in any investigation dealing with concepts transmission. Nevertheless, we intend not to disqualify possible contacts that Arabs might have had with other traditions, especially when attested historically. The kind of contact between the Arabs and the Greeks surely pertains to different domains, so that Versteegh (1977; 1993) distinguishes between a direct and an indirect influence, the former linked to the logical and philosophical traditions transmitted to Arabs through the translations of the Greek scholarship; the latter instead exercised through everyday contact between Arabic and Greek civilizations in the Byzantine

$6 \quad$ See also Brockelmann (1937, vol. I Suppl., 156).

7 We wish to remark that advocating this approach does not imply a total rejection of other viewpoints, especially with regard to the propositions, mostly advanced by Carter, of a deep relation between other Islamic sciences and the Arabic linguistic disciplines. The earliest stages of the Islamic era, scene of outstanding intellectual activities, witnessed the raise of a number of disciplines that were profoundly intertwined (e.g., theology, kalām; Qurānic exegesis, tafsìr; philology, qiräàat; law, fiqh). Given the profound connection among these sciences, scholars would be contextually working in different fields: for instance, scholars from linguistic studies would be working on the qirăa $\bar{t}$ and/or law as well, and this is testified also by the fact that the earliest grammatical treatises share the technical lexicon with a number of other Islamic scholarly disciplines. The significant role played by the Islamic disciplines in the development of the Arabic grammatical tradition is thus surely undisputed.

8 On the history of transmission of the Organon in the Middle East, see among others D'Ancona (2004), and the works by Hugonnard-Roche (1989; 2004; 2009). 
provinces. ${ }^{9}$ Historically, in both pre-Islamic and Islamic times, Arabs have been exposed to foreign erudition and have been in a deeper contact with traditions like the Greek, even before the attested tradition of translation of Greek works of the 4 th/1oth century.

Finally, our overview on the classification of the parts of speech will rely on possible points of convergence between the Arabic and the Greek tradition, as a possible reading of the transmission and development of grammatical concepts in the Arabic linguistic tradition. In fact, if on the one hand, it is surely true that the legal theory must be accounted for in this research, ${ }^{10}$ on the other hand, "borrowing grammatical terms does not imply a total dependency, Arabic grammar is a linguistic system in its own rights" (Versteegh 1977, 15), and thus the grammatical terminology should be analyzed deeply, also being open to possible connections to other traditions. This holds especially true for those terms that Carter (1972), too, considers as possibly influenced by other traditions. ${ }^{11}$

9 In the discussion on the subject, Versteegh points, on the one hand, to the geographical proximity as a possible reason for the con-penetration of ideas and concepts, and that thus may be accounted for in debating how "foreign" concepts and ideas might have reached the Arabs; and, on the other hand, to the movement of translation of the Greek works as a more direct type of influence. On this latter aspect, Versteegh addresses more specifically the Stoic linguistic theories. By comparing the resemblances in the formulations, and in line with Versteegh's considerations, in our discussion we hence wish to remark on the possibility that concepts might have circulated, reaching the Arabs. We suggest that the possibility that Greek concepts might have circulated in the early Islamic context and before the time of the translations of the Aristotelian works should not be ruled out entirely. With this, however, we do not aim to deny the Arabicity of the Arabic linguistic tradition, nor the original contributions of the earliest grammarians to the formulation and development of the linguistic science; our approach rather aims at discussing possible influences in the metalinguistic dimension, on which Arabic grammarians might have drawn in their studies. Finally, we do acknowledge again the evident difficulties in reconstructing possible ways of transmission, especially as we lack substantial portions of the Stoic tradition and any respective Arabic translations, nor do we have evident proofs of any Syriac intermediary, as the Greek linguistic texts that were translated into Syriac (e.g, the Technē Grammatikē) do not seem to have been translated into Arabic.

10 Carter $(1972 ; 1983)$ further argues that Sỉbawayhi's grammatical practice was an application of legal methodology and terminology to linguistic analysis. However, as also pointed out by Owens, "Carter has never shown in any detail, either terminologically or methodologically, how this transference occurred, nor has he entertained (i.e., falsified) the possibility that the direction of influence was in the opposite direction, or that the disciplines developed parallel but largely separately" (Owens 2005, 106).

11 Carter mentions $(1972,80)$ that some categorial terms of the linguistic lexicon (e.g., ism ['noun'], fi' ['verb'], and harf'[particle']) may have been borrowed from other traditions, and that the methodical lexicon comes instead from the field of legal studies (figh). 
Conversely, the arguments in favor of the external influences have witnessed a number of rather ventured statements. So for instance, Merx (1889) has proposed that Arabic grammar might have somewhat stemmed from Greek logic. The propositions advanced by Merx were built on six notions that had allegedly been imported from the Greek tradition into the Arabic: the use of the three parts of speech; 'i'rāb; the notion of gender; zarf; the notion of hāl; the notion of predicate. In his discussion, Merx argues that such notions had been received in the Arabic tradition via their Aristotelian propositions "ea vero, in quibus Grammatici notionibus ab Aristotele propositis usi sunt" (Merx 1889, 141). ${ }^{12}$ The arguments mostly draw on terminological similarities and conceptual connections between technical terms.

More specifically on the topic of this paper, Merx argues that the use of the three parts of speech in Arabic (noun, verb, and particle) would be connected to the Aristotelian noun, verb, and conjunction. The distinction is based on Aristotle's proposition and on the additional definitions provided by later Arabic grammarians.

However, Sïbawayhi surely does not qualify as an "Aristotelian" scholar: in the Arab-Islamic world, these would rather be figures such as al-Fārābī (d. 339/950) and Ibn Rušd (d. 595/1198), who surely could not have influenced Sibawayhi. However, it still is reasonable not to rule out in advance the possibility that already at the time of Sibawayhi, Arabs might have had access to such notions and therefore grammarians might have partly drawn on these for their linguistic theorizations. Thus, if we assumed an earlier circulation of concepts from the Greek tradition and a possible Arabic reception of the Aristotelian works, perhaps via the Syriac medium, ${ }^{13}$ this would have made possible a development of the Arabic linguistic disciplines under some more general Hellenistic influence:

12 As reminded by Versteegh, "Rundgren (1976) revived Merx' thesis by pointing out that even before the period of the translations some knowledge of Greek logic and philosophy had reached the Arabs through the Persian translations that had been made at the academy of Gundishapur. These Persian translations had been translated into Syriac and some elements of Greek logic had even become available in Arabic through a treatise on logic by. Ibn al-Muqaffa', either the famous translator of the Kalila wa-Dimna (d. 142/759) or his son Muhammad ibn 'Abdallah Ibn al-Muqaffa' (d. $\pm 200 / 815)$ " (Versteegh 1993, 23).

13 The studies on the Syriac reception of Greek works and their transmission into Arabic are extensive. Among these, see in particular the already-cited works by Hugonnard-Roche (1989; 2004; 2009); and Troupeau (1991), who discusses how "Pour faciliter la tache des traducteurs du grec en syriaque et du syriaque en arabe, les savants syriaques constituerent de veritables lexiques, sur le modele des recueils de mots « ambigus », qu'ils avaient composes pour les besoins de l'exegese et de la grammaire"(Troupeau 1991, 10). See also López-Farjeat (2019), who presents the role played by the Syriac tradition in the transmission of Greek philosophy into the Islamic context, emphasizing the role of Christian Syriac translators and discussing the impact of Aristotle's Categoriae. Finally, see also Brock (2007). 
Nicht indischer Phantasie, sondern griechischen Geistes bedurfte es dazu, das Nachdenken auf die Erkenntnis des Wirklichen zu richten. [...] Überall, wo es sich nicht um bloßes Aufzählen oder zufälliges Zusammenreihen handelt, sondern nach sachlichen oder logischen Gesichtspunkten eine Anordnung des Mannigfaltigen versucht wird, darf mit Wahrscheinlichkeit auf griechischen Einfluss geschlossen werden. (de Boer 1901, 17)

\section{$2 \quad$ Parts of Speech ${ }^{14}$}

In general, the major division on which a classification of the parts of speech is founded regards the opposition between nouns and verbs, in their functions as subjects/topics and predicates:

There must be something to talk about and something must be said about this subject of discourse... The subject of discourse is a noun... No language wholly fails to distinguish noun and verb, though in particular cases the nature of the distinction may be an elusive one. It is different with the other parts of speech. Not one of them is imperatively required for the life of language. (Sapir 1921, 21)

A preliminary distinction is so to be made between these two substantial elements, whereas all others could well be perceived as not representing the fundamentals of the discourse, but rather as subcategories of the major two. ${ }^{15}$

When assessing the classification of an element as either a part of speech, or as a class within one of the categories, the criteria used to determine its status pertain to the function that such element may assume. ${ }^{16}$ Fundamentally, the identification of an element as a part of speech accounts for a number of essential characteristics (e.g., semantics) as well as of secondary characteristics

14 The discussion on the topic is of course much wider than the few concepts that we may discuss here. For the purpose of our discussion, we will then only highlight some of the major themes that are relevant to our matter.

15 This applies especially to the first category, that of nouns, which can be more easily adjusted so as to include further classes. As we will see further in this paper, the category of verbs is much more restricted, as it relates to 'action', whereas that of nouns may be more freely interpreted, inasmuch as its elements partake of a concept of 'meaning'.

16 For the purpose of our discussion, we will summarize here the main concepts on which we will draw for our examination. For a wider discussion on the matter, see Versteegh (1977, $38-89)$. 
(e.g., morphology). The essential characteristics are, of course, of major importance, whereas the secondary features are considered as collateral. So, for instance, if two elements differ only in the way they are inflected but other than that formally correspond to each other, such difference in the inflection will not be enough so as to consider the two as distinct parts of speech. Taking Arabic as an example, common nouns and proper nouns would be in the same category because they would differ, essentially, in the inflection, which would be either triptotic or diptotic. From this, a principle of syntactic interchangeability emerges as an underlying condition, so that something that may replace a word is identical with that word, and therefore belongs to the same category.

\subsection{Greek}

In the Greek tradition, grammar would be treated as a branch of philosophy. The correctness of language usage would be codified in a number of rules, and therefore grammar would essentially represent a set of regulations aiming to prescriptively indicate how to shape the discourse.

The earliest observations on the language as a structured system are available in the Socratic scholarship. ${ }^{17}$ Later in Plato (d. 348/347 BCE), we find an earliest attestation of grammatical studies, specifically in the Cratylus, ${ }^{18}$ in which the traditional classification of the parts of speech originates. In this Dialogue, we have an initial division that includes two elements, ovvor (ónoma) 'noun', and $\hat{\eta} \mu \alpha$ (rhèma) 'verb':

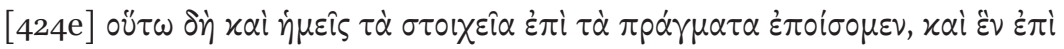

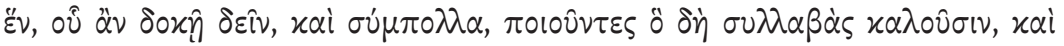

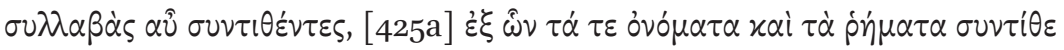

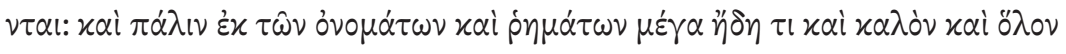

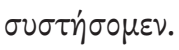

[424e] In just this way we, too, shall apply letters to things, using one letter for one thing, when that seems to be required, or many letters together, forming syllables, as they are called, and in turn combining syllables, [425a] and by their combination forming nouns and verbs. And from nouns and verbs again we shall finally construct something great and fair and complete. (Cratylus, 424e-425a)

17 5th century BCE.

18 Greek works have been accessed through the portal Thesaurus Linguae Graecae (TLG) (http://stephanus.tlg.uci.edu/). For the translations, we relied on those made available by the Perseus Digital Library (perseus.tufts.edu/hopper) via the TLG. When consulted, the online Liddell-Scott-Jones Greek-English Lexicon (LSJ) has been accessed through the TLG portal as well. References to the single editions are available in the bibliography. 
Nouns are elements that can function as terms (i.e., subject or topic) in a clause, whereas verbs are words that can function as predicates. Plato first addresses the results of the combination of a number of elements - letters that combined shape words, in this case - and moves forward to explaining how these words may function in a structured system:

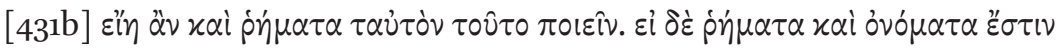

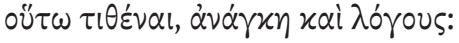

[431b] And if verbs and nouns can be assigned in this way, the same must be true of sentences; for sentences are, I conceive, a combination of verbs and nouns. (Cratylus, 431b)

In Aristotle (d. 322 BCE) the formulation is presented in a slightly different way. He well maintained his teacher's basic distinction, but added a third class of elements, the súndesmos, ${ }^{19}$ conjunctions, specifically elements acting as connectors for words and phrases: ${ }^{20}$

$$
\begin{aligned}
& \text { övopa (ónoma) 'noun' (Rhetorica, 1404b); } \\
& \text { în } \mu \alpha \text { (rhèma) 'verb' (Poetica, 1457a); }
\end{aligned}
$$

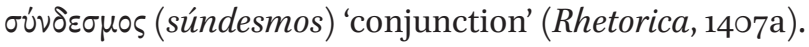

Further formulations presented by Stoic philosophers design instead a fourelement classification of the parts of speech, to which a fifth is also commonly added: proper names, common nouns (or appellatives), verbs, connectors / conjunctions, and articles.

The biographer Diogenes Laertius presents the matter in the Vitae Philosophorum, in the chapter about Zeno of Citium (d. 261 BCE), founder of the Stoicism:

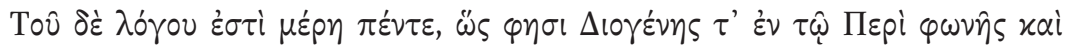

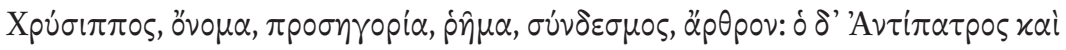

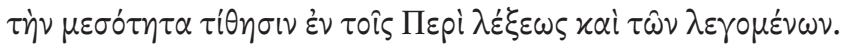

There are, as stated by Diogenes [of Babylon] in his treatise on Language and by Chrysippus, five parts of speech: proper name, common noun,

19 Another term that may be found in Arabic, and that perhaps better fits in the Aristotelian concept, is ribāt, a calque of the Aristotelian part of speech which occurs in the Arabic translations of Aristotelian works (e.g., the translation of the Poetica by Ibn Sīnā [d. 428/1037]).

20 The Greek tradition will not rely on this Aristotelian formulation, but on that by Dionysius Thrax (see infra). However, this classification is still at times preserved. 
verb, conjunction, article. To these Antipater in his work On Words and their Meaning adds another part, the "mean." ${ }^{21}$ (VII: 57)

A collection of the Stoic propositions is also available in Sextus Empiricus' work, ${ }^{22}$ in which he elucidates the development of the grammatical schools and their positions. With the non-Aristotelian scholars, we then find a classification of the parts of speech with more than three elements, starting with the Stoicism. But it is in the Techne Grammatikē, the work attributed to the Alexandrian grammarian Dionysius Thrax (2nd century BCE), ${ }^{23}$ that we first find the system of eight parts of speech. In addition to the five parts of speech presented by the Stoics, Dionysius Thrax recognized also participles, pronouns, and prepositions: ${ }^{24}$

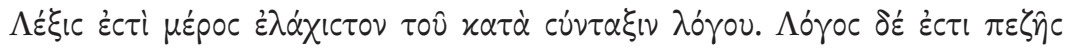

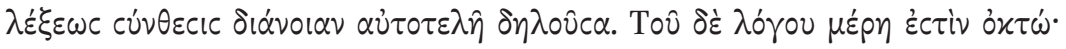

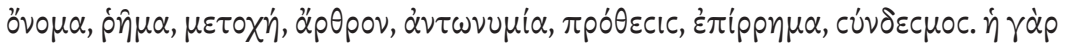

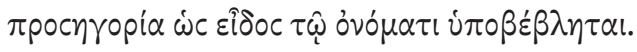

A sentence is combination of words, either in prose or in verse, making complete sense. There are eight parts of speech: Noun, Verb, Participle, Article, Pronoun, Preposition, Adverb, and Conjunction. The proper noun, as a species, is subordinate to the noun. (Technē Grammatikē 1905, Part 1, vol. 1, p. 22)

21 Possibly an adverb, as elucidated in the footnote to the text.

22 Cf. Sextus Empiricus, Adversus Mathematicos (I, 132).

23 The authorship of the Ars Grammatica is debated, and the dating of the text depends on such discussion. For the discussion on the authorship, see Di Benedetto $(1958 ; 1959)$, who states that "la Techne non è la prima trattazione sistematica in materia, opera di uno scolaro di Aristarco, ma un modesto manuale, composto, come altri trattatelli e i Canoni di Teodosio, intorno al IV sec. d.C. (più precisamente si oscilla tra il III e il V sec. d.C.). Essa è un documento della cultura grammaticale di questi secoli, priva ormai di spirito creativo e ridotta a mere com pilazioni, come il Pseudo-Trifone" (Di Benedetto 1959, 118). To date, there seem to be a general agreement that the work is rather the result of the compilation of chronologically heterogeneous materials, as also suggested by Contini,: "[...] gli storici della linguistica sembrano concordare in linea di massima nel vedere nella $T G$ un trattato compilativo che integra frammenti di data assai varia, ma divergono sensibilmente nella collocazione cronologica da assegnare alla sostanza delle conoscenze grammaticali riflesse nel breve trattato" (Contini 1998, 96).

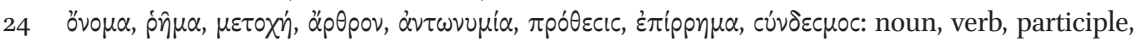
article, pronoun, preposition, adverb, and conjunction. Traditional grammar has ever since relied heavily on this formulation, and all classifications that followed have been based more or less on the system derived by Dionysius Thrax' propositions. 


\subsection{Arabic}

In the Arabic linguistic tradition, the first formulation on the parts of speech is in Sībawayhi's Kitāb, with the well-known formulation:

\section{fa-l-kalim: ism wa-fil wa-harf ğāa li-ma'nā laysa bi-sm wa-lā-fil}

Words are noun, verb, or particle with a meaning that is neither that of the noun nor of the verb (Kitāb, I: 1)

The basic division, thus, consists of three major elements, ism, fil, and harf, 'noun', 'verb', and 'particle', respectively:

The most fundamental classification of words recognized by the medieval Arab grammarians is the well-known three-fold classification into noun (ism), verb $\left(f^{i} l\right)$ and particle (harf). Said to have been first enunciated in Islam by none other than the Caliph 'Alī, this classification has remained to the present day a leading principle of Arabic grammar and is regularly set forth in the opening pages of grammar books still used in the Muslim East. Even the Wright-Caspari grammar, taken still to be the classic Arabic grammar in English, treats the three classes of words as «parts of speech», subsuming the parts of speech traditionally recognized in English grammars under them. (Weiss 1976, 23) ${ }^{25}$

Weiss, when presenting the "most fundamental classification of words", rightly mentions the type of subdivision that was firstly advanced by Sỉbawayhi and then - almost - unanimously ratified and perpetuated, and that is anterior to the introduction of logic into the Arabic tradition. ${ }^{26}$

Later, and although any of these has ever been fully endorsed, there have been few attempts to propose formulations different from that in the Kitāb. So for instance we find a fourth element, hālifa, in al-Suyūțì (d. 911/1505), ${ }^{27}$ and al-Fārābī, too, mentions the elements huawālif. ${ }^{28}$ Notwithstanding, in his "purely

25 Weiss presents the parts of the speech investigating them as "A study in "ilm al-wad", which "may be translated as the founding of language, [and] represents a concept that is central to classical Muslim scholarly thinking about language" (Weiss 2009, 684).

26 "Die Auffassung, als gingen bei den Arabern die Anfänge der Logik denen der Grammatik voraus ist ein Hysteronproteron, das die Folge der historischen Tatsachen auf den Kopf stellt" (Weiß 1910, 386).

27 'Ašbāh (III: 2).

28 Zimmerman (cf. 1991) translates hawālif (sg. hälifa) as 'substitute', used by al-Fārābì as the equivalent of 'pronoun'. In addition, it should be noticed that "several philosophical sources 
Aristotelian writings",29 al-Fārābī follows the tripartite division (cf. Versteegh 1995, 41, fn. 29). Another example of this is in Ahmmad Makkī al-Anșārī who, investigating the role of al-Farrä (d. 207/822) in the Arabic linguistic tradition as the leading figure of the grammatical school of Küfa, further states that al-Farrā' was the first to propose a fourth lexical category between the noun and the verb.

Due to some inconsistencies in the use, as well as to the diverse propositions advanced, Talmon set forth the thesis that the parts of speech were hence an unstable system (Talmon 1997, 280). In his argument, he mostly referred to the case of the ism, considering the "semi-independent status" of the nat in the Kitäb al-Ayn, "in its frequent contrast to ism", as an indication that early grammarians may have been inspired by an older division into eight parts of speech. ${ }^{30}$ Talmon notes that this "is also observable in the Kitāb, but in a smaller degree" (Talmon 1997, 280).

In addition to Talmon's viewpoint on this, Suleiman's assertions on the matter are also rather representative:

Sībawaihi relies on a mixture of elements in the delimitation of the three word-classes he establishes in Arabic. Thus, he invokes what is essentially a notional or conceptual consideration in delimiting the 'particle'. Furthermore, this is carried out in a manner which suggests that both the 'noun' and the 'verb' are susceptible to notional delimitation, as is evident from the 'negative mode' adopted by Sībawaihi in delimiting the particle, although no such delimitation is given in the Kitäb. In delimiting the verb, Sībawaihi also advances what is essentially a morphological, or morphosyntactic, consideration, as is clear from his reference to the states of the verb and the types of conjugations subsumed under it. (Suleiman 1990, 248)

demonstrate that there was a general awareness of the connection between the grammatical term harf (together with ism and $f_{i} \tau$ ) and the philosophical term ribätt (together with ism and kalima). Such a connection is established, for instance, by al-Fārābī (ك̌arh 54.8-9), by al-Ȟwārizmī (Mafātīh 145.13-14) and by Ǧābir ibn Ḥayyān (see Kraus 1942:11, 250)" (Versteegh 1995, 36, fn. 16).

29 al-Fārābī also mentions a direct reference to Greek scholars: "min 'ahl al-lisān al-yūnānı̄" (Kitāb al-'Alfäz, 42).

30 See the classification put forth by Dionysius Thrax mentioned above. 
In Arabic, the classes belonging to the category of nouns include, inter alia: adjectives (șifa, $\left.n a^{c} t\right)$, plus assimilate and comparative adjectives (șifa mušabbaha and 'af'al al-tafḍill); adverbs (zarf); pronouns (damìr). ${ }^{31}$

As pointed out by Kasher, this classification by Sỉbawayhi's presents a few criticalities in its formulation:

The first topic Sībawayhī treats in his al-Kitāb is the division of Arabic words (or morphemes) into three parts of speech (Sïbawayhī, al-Kitāb I: 1). His classification, albeit (as far as we know) unanimously endorsed by his followers, raises many theoretical problems, not least of which is the abundance of cases in al-Kitäb, as well as in later grammatical treatises, where the phraseology implies that the classes referred to by the terms sifa and ism form a mutually exclusive pair, despite the fact that sifa refers (in the contexts in question) to a subclass of the part of speech ism. (Kasher 2009, 460$)^{32}$

The criticalities addressed by Kasher are utterly well founded, especially considering that Sībawayhi disregards any explanations of why the parts of speech in Arabic would be three, and why those classes would be considered as part of said category. Moreover, in light of the functions and usage of some of the classes of the part of speech ism, these may easily be classified as additional parts of speech for themselves.

However, the division surely did not seem to be problematic for Arabic grammarians, who do not accentuate any type of confusion that the traditional classification may bring: ${ }^{33}$

31 Baalbaki presents the matter in relation to how subdivisions of the same part of the speech

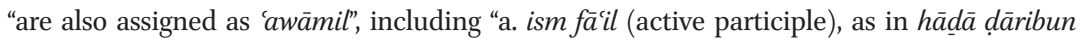
Zaydan gadan; b. șifa mušabbaha (assimilate adjective), since this is said to be assimilated to ism fäil (cf. al-hasanu l-wağhi and al-ḍāribu l-rağuli); c. ism maf'ül (passive participle), as in a-Zaydan anta mukäbarun 'alayhi; d. af'al al-tafḍil (comparative af'al), as in huwa ahsanu minka wağhan; e. nisba (gentilic adjective; referred to by Sībawayhi as ị̂āfa), as in a-Qurašizyyun qawmuka; f. mașdar (verbal noun), as in 'ağibtu min darbin Zaydan Bakrun; g. ism ficl (lit. proper name of the verb), as in ruwayda Zaydan and hayyahala l-tarìda; and h. 'adad (number), as in 'išriña dirhaman which Sībawayhi likens to ḍāribīna 'Abdallāhi" (Baalbaki 2008, 89-9o).

32 As mentioned by Kasher, "Such a case was noted already by Diem (1974: 320), although the way he resolves it differs from the one which will be proposed below." See on this Diem (1974).

33 The fact that the tripartite division would not be challenged is also set up as a rather straightforward consequence of a common agreement. As the formulation and transmission 
The term 'ism, for instance, once introduced by Sîbawayhi as a grammatical term denoting a noun, was used as such throughout, causing little confusion- It is rare for any ambiguity between 'noun' and 'name' to arise. Furthermore, the grammarians introduced terms denoting sub-categories of 'ism, such as shay', shakhș, juththah and 'ayn, broadly denoting an object, and hadath denoting an event. Apart from the latter term, each of these expressions is normally used in medieval metalinguistic discussions as a grammatical term. (Peled 1999, 53)

After introducing the parts of speech, Sỉbawayhi presents the category of nouns by introducing the linguistic arguments by means of examples (tamtīi), instead of addressing their grammatical functions:

fa-l-ism: rağul, wa-faras, wa-hā̇it

And the noun is 'man', and 'horse', and 'wall' (Kitāb, I: 1)

Although the Greek definitions discuss more in detail grammatical functions of the elements at issue, rather than relying on examples, formulations by way of examples and similar to that of Sībawayhi are available in Greek works as well. ${ }^{34}$ Thus, we may encounter definitions such as that by Plato:

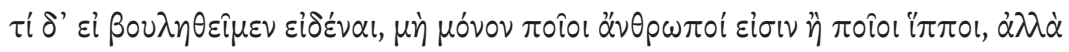

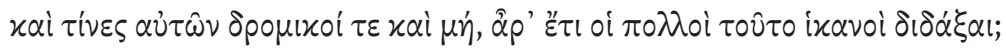

But what if we wished to know not only what men were like or what horses were like, but which of them were good runners or not? Would the many still suffice to teach us this? (Alcibiades, 1,111 )

of the categories stem from a reached consensus, 'iğma $\bar{a}^{c}$, "one of the most frequently cited criteria for the correctness of a linguistic expression or even a grammarian's reasoning and as such it is related to the use of unanimity as an argument by the theologians." Versteegh further continues arguing that "In grammatical discussions we find, for instance, the unanimity of the grammarians (pp. 52, 79) or the unanimity of the Kufans and the Basrans (p. 202 'igmā' al-Kufiyyīn wa-l-Basriyyīn). In Ibn al-'Anbārì's analysis of linguistic criteria we find the statement that unanimity is a decisive argument (huğğa qāticia, Luma' 44.9, 47.2)" (Versteegh 1995, 30, fn. 2).

34 Although the arguments we are advancing here with regard to the classification of the parts of speech and the definition of the category of nouns are in line with the earliest Greek formulations on the matter, namely as per in Plato and Aristotle, we here wish to remark that the Greek tradition has then mostly followed the formulations by Dionysius Thrax. However, as in our discussion we are trying to stress possible connections, we will mostly refer to the earlier works that we believe might have had an influence on the Arabic tradition, and not to the later standard doctrine. 
Or that by Aristotle:

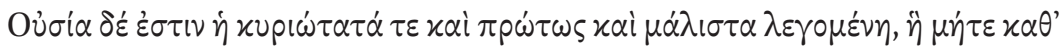

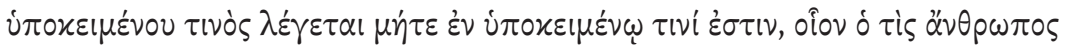

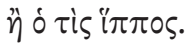

Substance, in the truest and primary and most definite sense of the word, is that which is neither predicable of a subject nor present in a subject; for instance, the individual man or horse. (Categoriae, 2a 14)

Both the excerpts quoted above show some similarities with Sïbawayhi's formulation, also with regard to the examples used, man and horse. ${ }^{35}$ However, what we find in the Greek instances, and that is definitely lacking in the Arabic, is the elucidation of the grammatical characteristics of the noun as a part of speech. In fact, Sïbawayhi does not provide a real definition. Thus, to investigate the types of arguments devised for the purpose, we need to move further and examine later works.

A first formulation is in the al-Muqtadab by al-Mubarrad (d. 286/900), who asserts that:

A noun is everything that can be preceded by a preposition, and if it is not possible then it is not a noun. (al-Muqtadab, I: 141)

Later, in the al-Ṣăhibī by Ibn Fāris (d. 395/1004), we find a report of earlier arguments, ${ }^{36}$ presented as follows:

As for the noun, Sībawayhi says: "The noun is for instance man and horse" [...] and states Abū l-'Abbās Muhammad b. Zayd al-Mubarrad that according to Sỉbawayhi's view: "The noun is what can be a subject," [...] and states al-Kisāî̀: "The noun is what an attribute can be referred to," and says al-Farrā': "The noun is what can exhibit a tanwinn, and be in construct state or annexed to the definite article," and says al-Ahfaš: "You know that

35 Further resemblances are observed by Versteegh who states that "in Sibawayhi's Kitab the primary examples for the noun are rağul "man" and faras "horse", which correspond with the well-known examples of the Stoic school tradition anthropos and hippos. In both traditions the verb "to hit" (túpto/daraba) is the most popular example for the category of the verbs" (Versteegh 1993, 23).

36 Further recollections of the opinions on the noun, although discussed from a different viewpoint (cf. Olivieri 2017), are also available in the twelfth-century Kitāb al-'Inșāf by Ibn al-Anbārī (d. 577/1181) who, in the general discussion on the ism states that "the noun [is what] can operate as predicate and predicator" (Kitāb al-'Inșāf, 6). 
you are dealing with a noun when a verb or an attribute can be referred to it, as for instance in zayd qāma (Zayd stood) or in zayd qã ìm (Zayd is standing), when can be in the dual form or take the plural, as al-zaydanni (the two Zayd(s)) and al-zaydūna (the Zayd(s)), and when exhibits a triptotic inflection. (al-Sāhibī, 49)

Finally, of all exemplifying definitions, the one by al-Zağğăğ (d. 311/923) seems to be of particular interest, for it shows a number of more evident resemblances with the Greek, so in that:

[The noun is] an articulated and comprehensible sound that expresses a meaning but has no implications of time and space. (al-Zağğăğ, quoted by Ibn Fāris, al-Ṣăḥibì, 51 )

may well be put in correlation with:

A noun is a composite sound with a meaning, not indicative of time, no part of which has a meaning by itself; for in compounds we do not use each part as having a meaning of its own (Poetica, 1457a). ${ }^{37}$

\section{$4 \quad$ Discussion}

In line with these general approaches, if a preliminary distinction is to be made between verbs and nouns, the two fundamental elements, ${ }^{38}$ then all others may be associated with each other insomuch as they partake with the concept of being the expression of what lays below. ${ }^{39}$ It then becomes customary to group the noun and the adjective together because all elements that share characteristics that do not belong to that of the verb, would form a category for

37 On this, Farina notes that in 'Amīra's Grammatica Syriaca (16th cent.) "[...] three definitions of the noun attributed to different Syriac grammarians (Elias of Nisibis, John the Stylite and the «Grammar in Arabic language») are quoted, both in their Syriac form and in Latin translation, and then compared. The latter one, that 'Amira considers as the most complete and the clearest, is then discussed and commented upon in detail. Such a definition, in 'Amīra's Latin translation, reads: «Nomen est vox significative in perfectione, quae sine tempore est, qua pars cum separatur, non significat aliquid»" (Farina In press, 20). The definition highlighted here by Farina corresponds, word-by-word, to Aristotle's definition.

38 See above, $\S 2$.

39 Cf. Kitāb al-'Inșâf, 2. 
themselves as opposed to the verbs. ${ }^{40}$ Therefore, anything that points at the meaning of its nominatum may be considered as a noun. ${ }^{41}$

In Greek grammatical literature the ónoma may indicate any word that refers to the nominatum, 'the named one'. Similarly, al-Mubbarad's approach to the matter, distinctly in line with Sîbawayhi's proposition, also considers the 'asma $\bar{a}$ ' as elements to be used for all words that may be regarded as the 'name' of its meaning (musammā, 'nominatum'):42

The noun refers to the nominatum below [...] And since the noun is raised above the nominatum and stands above its meaning, this means that it is derived from simuww and not from wasm. (al-Mubarrad, as in Kitāb al-'Inșāf, 2)

Similar oppositions based on the meaning conveyed may be found in Aristotle's De Interpretatione, which focuses on the concept that the meaning of the verb is the 'action', and when being conjugated, the tenses add a time axis to it:

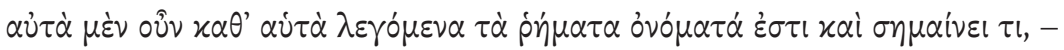

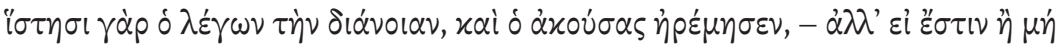

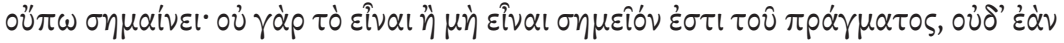

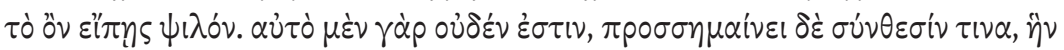

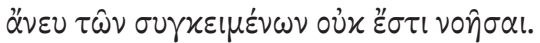

When uttered just by itself a verb is a name and signifies something--the speaker arrests his thought and the hearer pauses--but it does not yet signify whether it is or not [the meaning]. For not even 'to be' or 'not to be'

40 Cf. Lyons (1966), who argues that "from Alexandrian times it has been customary to group the noun and the adjective together (the distinction of 'nomen substantivum' and 'nomen adjectivum' as separate 'parts of speech' being a medieval development" [...]) and to distinguish them sharply from the verb" (Lyons 1966, 216).

41 According to this, the harf ('particle') could not be included in this category, as Sïbawayhi's statement that the harf has a meaning that is neither that of the noun nor of the verb (Kitäb I:1) is interpreted so that particles convey a meaning only when in combination with other words, and therefore do not have one themselves. For further discussions on this, also in relation with the other parts of speech, see Versteegh (1995, ch. III, especially fn. 35).

42 The idea of the reference to the underlying meaning is maintained in other works as recounted in the Kitāb al-'Inșāf, where we find: "the term derives from simuww, because in the Arabic lexicon it indicates the elevation: when something is elevated you say sama, yasmū, simuww. From this, the sky has been called $s a m \bar{a}^{3}$ because it is in the height, and [likewise] the noun stands above the signified and shows what is below, as far as the meaning is concerned" (Kitāb al-'Inșāf, 2). 
is a sign of the actual thing (nor if you say simply 'that which is'); for by itself it is nothing, but it additionally signifies some combination, which cannot be thought of without the components. (De Interpretatione, 16b, 19-25)

Thus, if any elements that points to a nominatum may be a noun, all the classes that we have mentioned above would straightforwardly be included in the category of noun as a logical conclusion, in both the Arabic and the Greek traditions. This correlation noun-nominatum, then, would be the principle for considering an element as part of said category. Similarly, but dealing with the matter from another angle, operates the principle of syntactic interchangeability that we have briefly mentioned above (cf. §2). Based on this, elements cannot be considered as separate parts of speech if they may replace a word and remain identical with that. A clear example of this is that of pronouns. So, taking again Arabic as an example, this is the case of the ism mudmar, ('hidden'), which as a personal pronoun denotes the noun it refers to; or of the ism mubham, ('ambiguous', because it is not clear what it refers to), which identifies the demonstrative pronouns.

From a semantic viewpoint, finally, the ism partakes of a number of similarities with the ónoma, at least as per its Aristotelian formulation. In both traditions, nouns are elements that possess an independent meaning, but do not provide references to time, differently from verbs that instead exhibit temporal (namely tense) features. Furthermore, in the Poetica we do not have those lists of nominal classes that we may instead find in the Technē Grammatikē.

Dionysius Thrax' linguistic formulations seem in fact to have been neglected altogether by Arabic grammarians, if they ever knew about these at all. Furthermore, the Technē Grammatikē "with its paradigms and system of verbal forms was completely foreign to the spirit of a Semitic language, and could in no way appeal to an Arab or Hebrew grammarian" (Fischer 1962, 2). The Aristotelian formulations, if we can go as far as to assume an influence, seem instead to be well received in the Arabic tradition.

If any connection with regard to the classification of the parts of speech is to be assumed, it would well rather be with the outline and grammatical compendium of the state of Greek language studies as presented in Aristotle's Poetica at the end of the fourth century BCE, as "whatever variations of the text may have confronted the Syriac and Arab translators, they considered it the final Aristotelian formulation, without any concern about the later, post-Aristotelian, developments in Greek grammatical science" (Fischer 1963, 133).

Surely, any of these arguments or similarities alone may ever prove a direct dependence of Arabic grammar from the Greek tradition, which is not our 
intent. However, the resemblances that the approaches show may hint at a contact with the Greek tradition. Similarities between the doctrines, taking as an example the earliest subdivision of the parts of speech advanced by Sibawayhi and the corresponding Aristotelian formulation in the Greek tradition, in fact, could never be explained by influence through translations of Greek writings, due to historical reasons.

However, we believe that albeit these arguments do not prove the influence of Greek logic which would instead come at a later stage, they might point at a possible contact with the grammatical outline set forth by Aristotle.

Sïbawayhi's premise with regard to the parts of speech, in fact, is largely relying on formulations that seem to be Greek-inspired, the type of griechischen Geistes suggested by de Boer (cf. 1901, 17, quoted above) and that Fleisch remarks as follows:

Des influences grecques sont à signaler: la spéculation grammaticale arabe a emprunté des concepts initiaux à la science grecque, non pas à la grammaire grecque, mais à la logique aristotélicienne. (Fleisch 1961, 23)

Furthermore, Fischer's studies in the 196os, and that we have quoted at length in this paper, have also advanced the idea that Aristotle's Poetica might have been more widely available in the "eastern part of the Mediterranean", and that its transmission and circulation might have been overlooked:

This lack of appreciation of the role played by the Syro-Arabic transmission of the Poetics was caused by several factors: i) In the Syro-Arabic transmission the Poetics often does not appear as a separate, independent treatise, but forms a part of the Organon and is joined to the Categories. It was thus placed, together with the Rhetoric, among the logical works of Aristotle. 2) Despite the fruitful translational activities of the Arabs, they were denounced as completely unfamiliar with Greek life and literature, and they were charged with all kinds of mis-conceptions, with the result that the value of Arabic interpretations outside the fields of philosophy and sciences was greatly reduced. This was especially true with regard to the literary and esthetic theme of the Poetics, which because of the obscurities of the text and stylistic difficulties presented additional linguistic problems. 3) The only attempt to confront the Arabic grammatical concepts with earlier Greek formulas was made on the basis of Dionysius Thrax' Technē Grammatikē which was used widely by the Syrian writers and is so well attested in Syriac grammatical science. (Fischer 1963, 4-5) 
It is rather evident that the possible points of convergence that may be found across Arabic and Greek works and that we have referred to so to support this case are circumstantial evidences, to say the least. Doubt may be cast on whether these same convergence points could be even read in a way that disqualifies the possibility at all. However, the possibility that Sỉbawayhi, or scholars either coeval or earlier, may have got in contact with the Greek tradition, is a suggestion that cannot be ruled out completely. This would ultimately point at a possible conceptual influence, rather than at a historical source; however, it is not illegitimate to ask whether Sībawayhi's theorizations on this fundamental issue of grammar may have been inspired by a grammatical framework external to the 'purest' Arabic tradition.

\section{References}

Ackrill, John L. 1963. Aristotle's Categories and De Interpretatione. Translated with Notes. Clarendon Aristotle Series. Oxford: Clarendon Press.

al-Fārābī. 1986. Kitāa al-'Alfāz al-Musta'mal fí-l-Manțiq. Edited by Muhsin Mahdi. Dār al-Mašriq.

al-Fārābī. 1991. Al-Farabi's Commentary and Short Treatise on Aristotle's "De Interpretatione." Translation, introduction and notes by F. W. Zimmermann. Classical and Medieval Logic Texts / The British Academy 3. Oxford: Oxford Univ. Press.

al-Mubarrad. 1965. Kitāb al-Muqtaḍab. Edited by Muḥammad 'Abdalhāliq 'Uḍayma. 4 vols. Cairo: Dār al-Taḥrīr.

al-Suyūțî. 1940. al-’Ašbāh wa-l-Nazậ̉ir fì l-Naḥw. 2nd ed. 4 vols. Hyderabad: Maṭba'at Dāirat al-Ma'ārif al-'Uțmāniyya.

Aristoteles. 20o9. Aristotelis Ars Rhetorica. Edited by William D. Ross . 18. Nachdr. Scriptorum classicorum bibliotheca Oxoniensis. Oxford: Oxford Univ. Press.

Aristoteles. 1991. Aristotle: in twenty-three Volumes. 23: The Poetics. Translated by W. Hemilton Fyfe. Repr. The Loeb classical library 199. Cambridge, Mass: Harvard Univ. Press.

Baalbaki, Ramzi. 2008. The Legacy of the Kitāb: Sibawayhi's Analytical Methods within the Context of the Arabic Grammatical Theory. Studies in Semitic Languages and Linguistics ; v. 51. Boston: Brill.

Boer, Tjitze J. de. 1901. Geschichte der Philosophie im Islam. Stuttgart: Frommanns Verlag. Bohas, Georges, Jean-Patrick Guillaume, and D. E. Kouloughli. 199o. The Arabic Linguistic Tradition. Arabic Thought and Culture. London; New York: Routledge.

Brock, Sebastian P. 2007. "A Syriac Intermediary For The Arabic Theology Of Aristotle? In Search Of A Chimera." In The Libraries of the Neoplatonists, edited by Cristina D' Ancona, 293-306. Philosophia Antiqua 107. Brill. https://doi.org/10.1163/ ej.9789oo4156418.i-536.20. 
Brockelmann, Carl. 1937. Geschichte der Arabischen Literatur. Leiden ; New York: E.J. Brill.

Burnet, John. 1901. Platonis opera. Scriptorum classicorum bibliotheca Oxoniensis. Oxford: Clarendon Press.

Carter, Michael G. 1972. "Les Origines de la Grammaire Arabe." Revue Des Études Islamiques 40: 69-97.

Carter, Michael G. 1983. "Language Control as People Control in Medieval Islam: The Aims of the Grammarians in Their Cultural Context." Edited by Ramzi Baalbaki. Al-Abhāt 31: 65-84.

Carter, Michael G. 2001. "A Missing Link between Law and Grammar, the Intișār of Ibn Wallād." Arabica 48 (1): 51-65.

Contini, Riccardo. 1998. "Considerazioni interlinguistiche sull'adattamento siriaco della Téchne Grammatiké di Dionisio Trace.” In La diffusione dell'eredità classica nell'età tardoantica e medievale: atti del seminario internazionale di studio, RomaNapoli, 25-27 settembre 1997. Il Romanzo di Alessandro e altri scritti, edited by Rosa Bianca Finazzi and Alfredo Valvo, 95-111. L'eredità classica nel mondo orientale 2. Alessandria: Edizioni dell'Orso.

D’Ancona, Cristina. 2004. "Greek into Arabic: Neoplatonism in Translation." In The Cambridge Companion to Arabic Philosophy, edited by Peter Adamson and Richard C. Taylor, 1st ed., 10-31. Cambridge University Press. https://doi.org/10.1017/ CCOLo521817439.002.

Di Benedetto, Vincenzo. 1958. "Dionisio Trace e la Techne a Lui Attribuita." Annali Della Scuola Normale Superiore Di Pisa. Lettere, Storia e Filosofia 27 (3/4):169-210.

Di Benedetto, Vincenzo. 1959. "Dionisio Trace e La Techne a Lui Attribuita (Continuazione e Fine)." Annali Della Scuola Normale Superiore Di Pisa. Lettere, Storia e Filosofia 28 (1/2): 87-118.

Diem, Werner. 1974. "Nomen, Substantiv und Adjektiv bei den Arabischen Grammatikern." Oriens 23-24: 312-32. https://doi.org/10.2307/1580108.

Diogenes Laertius. 1972. Vitae Philosophorum [Lives of Eminent Philosophers]. Edited by Robert Drew Hicks. Cambridge: Harvard University Press.

Farina, Margherita. In press. "Amīra's Grammatica Syriaca: Genesis, Structure and Perspectives." In Proceedings of the Workshop Typographia Linguarum Externarum - The Medici Oriental Press. Knowledge and Cultural Transfer around 1600 Florence 11-12 January 2018. https://hal.archives-ouvertes.fr/hal-o2115865.

Fischer, J. B. 1962. "The Origin of Tripartite Division of Speech in Semitic Grammar: I." The Jewish Quarterly Review 53 (1):1-21. https://doi.org/10.2307/1453419.

Fischer, J. B. 1963. "The Origin of Tripartite Division of Speech in Semitic Grammar (Continued)." The Jewish Quarterly Review 54 (2): 132-6o. https://doi. org/10.2307/1453569.

Fleisch, Henri. 1961. Traité de Philologie Arabe. Vol. 1: Préliminaires, Phonétique, Morphologie Nominale. 16. Beyrouth: Imprimerie Catholique. 
Guillaume, Jean-Patrick. 1988. "Le Discours tout Entier est Nom, Verbe et Particule: Elaboration et Constitution de la Théorie des Parties du Discours dans la Tradition Grammaticale Arabe." Langages 23 (92): 25-36. https://doi.org/10.3406/ lgge.1988.1997.

Hugonnard-Roche, Henri. 1989. "L’Organon. Tradition Syriaque et Arabe, les Premiers Analytiques." In Dictionnaire Des Philosophes Antiques. Publié Sous Le Direction de Richard Goulet, Avec Une Préface de Pierre Hadot. I:Abam(m)on à Axiothéa, 516-520. Paris.

Hugonnard-Roche, Henri. 2004. La Logique d'Aristote du Grec au Syriaque: Études sur la Transmission des Textes de l'Organon et leur Interprétation Philosophique. Textes et Traditions 9. Paris: Vrin.

Hugonnard-Roche, Henri. 20o9. "La Tradition Gréco-Syriaque des Commentaires D'Aristote." In L'oeuvre de David l'Invincible et La Transmission de La Pensée Grecque Dans La Tradition Arménienne et Syriaque, 116:151-73. Philosophia Antiqua.

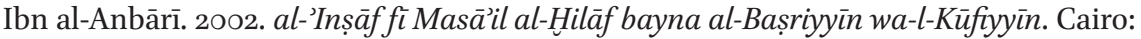
Maktabat al-Hुanḡì.

Ibn Fāris. 1963. al-Ṣāhibī fì Figh al-Luġa wa-Sunan al-Arab fı̈ Kalāmihā. Edited by Mușțafà al-Šuwaymī . Beirut: Mu’assasat Badrān.

Kasher, Almog. 2009. "The Term Ism in Medieval Arabic Grammatical Tradition: A Hyponym of Itself." Journal of Semitic Studies LIV (2):459-74. https://doi.org/10.1093/ jss/fgpoog.

Kraus, Paul. 1942. Jābir ibn Hayyān: Contribution à l'histoire des idées scientifiques dans l'Islam. II. Jābir et la science grecque. Cairo: Institut d'Egypte. (Repr., Paris: Les Belles Lettres, 1986.).

López-Farjeat, Luis Xavier. 2019. "La Tradición Siriaca como Intermediaria en la Transmisión del Pensamiento Filosófico Griego al Antorno Islámico: Las Categorías de Aristóteles." Estudios de Asia y Africa 54 (1): 27-56.

Lyons, John. 1966. "Towards a 'Notional' Theory of the 'Parts of Speech." Journal of Linguistics 2 (2): 209-36.

Merx, Adalbert. 1889. Historia Artis Grammaticae apud Syros / Composuit et Ed. Adalbertus Merx. Nachdr. [der Ausg.]. Leipzig: Nendeln, Liechtenstein : Kraus.

Mutschmann, Hermann, Jürgen Mau, and Karel Janáček. 1958. Sexti Empirici Opera. B G Teubneri.

Olivieri, Simona. 2017. "The Ism in the Arabic Grammatical Tradition: Reflections on its Origin and Meanings." Edited by Stephan Guth . Journal of Arabic and Islamic Studies 17 (Dossier spécial: Approaches to the Etymology of Arabic).

Olivieri, Simona. 2020. "The Formation of Arabic Grammatical Terminology: The Case of 'i'rāb." Zeitschrift für Arabische Linguistik 73: 5-25.

Owens, Jonathan. 2005. "The Grammatical Tradition and Arabic Language Teaching: A View from Here." In Investigating Arabic: Current Parameters in Analysis and 
Learning, edited by Alaa Elgibali, 42:101-116. Studies in Semitic Languages and Linguistics. Leiden: Brill.

Peled, Yishai. 1999. "Aspects of the Use of Grammatical Terminology in Medieval Arabic Grammatical Tradition." In Arabic Grammar and Linguistics, edited by Yasir Suleiman, 50-85. Surrey: Curzon.

Sapir, Edward. 1921. Language: An Introduction to the Study of Speech. New York: Harcourt, Brace \& World.

Scholia Dionysius Thrax. 1905. Scholia in Dionysii Thracis Artem Grammaticam. Edited by Alfred Hilgard . Leipzig.

Sībawayhi. 1966. al-Kitāb. Edited by 'Abd al-Salām Muhammad Hārūn . 5 vols. Cairo: Maktabat al-Hुānğì.

Suleiman, Yasir. 199o. “Sībawayhi's 'Parts of Speech' According to Zajjājī: A New Interpretation." Journal of Semitic Studies XXXV (2): 245-63. https://doi.org/10.1093/ jss/XXXV.2.245.

Talmon, Rafael. 1982. "Naḥwiyyūn in Sībawayhi's Kitāb." Zeitschrift für Arabische Linguistik 8: $12-38$.

Talmon, Rafael. 1985. "An Eighth-Century Grammatical School in Medina: The Collection and Evaluation of the Available Material." Bulletin of the School of Oriental and African Studies 48 (02): 224. https://doi.org/10.1017/Soo41977Xooo33322.

Talmon, Rafael. 1997. Arabic Grammar in Its Formative Age: Kitāb Al-'Ayn and Its Attribution to Halïl b. Aḥmad. Studies in Semitic Languages and Linguistics 25. Leiden ; New York: Brill.

Talmon, Rafael. 200o. "The First Beginnings of Arabic Linguistics: The Era of the Old Iraqi School." In History of the Language Sciences. An International Handbook on the Evolution of the Study of Language from the Beginnings to the Present, edited by Sylvain Auroux, E. F. K. Koerner, Hans-Josef Niederehe, and Kees Versteegh, 1:24552. Berlin: Walter de Gruyter.

Talmon, Rafael. 2003. Eighth-Century Iraqi Grammar: A Critical Exploration of PreHalilian Arabic Linguistics. Harvard Semitic Museum Publications 53. Winona Lake, Ind: Eisenbrauns.

Talmon, Rafael. 2008. "Jacob of Edessa the Grammarian." In Jacob of Edessa and the Syriac Culture of His Day, edited by R.B. ter Haar Romeny, 159-187. Monographs of the Peshițta Institute, Leiden, v. 18. Leiden ; Boston: Brill.

Troupeau, Gérard. 1991. "Le Rôle Des Syriaques dans la Transmission et l'Exploitation du Patrimoine Philosophique et Scientifique Grec." Arabica 38 (1):1-10.

Versteegh, Kees. 1977. Greek Elements in Arabic Linguistic Thinking. Studies in Semitic Languages and Linguistics 7. Leiden: Brill.

Versteegh, Kees. 1993. Arabic Grammar and Qur'anic Exegesis in Early Islam. Studies in Semitic Languages and Linguistics 19. Leiden; New York: E.J. Brill. 
Versteegh, Kees. 1995. The Explanation of Linguistic Causes: Az-Zağğāğı̀s Theory of Grammar. Amsterdam Studies in the Theory and History of Linguistic Science Ser. 3, Studies in the History of the Language Sciences 75. Amsterdam: Benjamins.

Viain, Marie. 2017. "Les Aléas Du «mot» Dans La Tradition Grammaticale Arabe: Conditions Taxinomiques, Sémantiques et Morphophonologiques de Son Appréhension." Bulletin d'études Orientales, no. 65 (April): 65-76. https://doi.org/ $10.4000 /$ beo.4817.

Weiss, Bernard. 1976. "A Theory of the Parts of Speech in Arabic (Noun, Verb and Particle): A Study in "ilm Al-Waḍc." Arabica 23 (1): 23-36.

Weiss, Bernard. 20og. "Waḍ ' Al-Lugia." In Encyclopedia of Arabic Language and Linguistics, IV:684-86. Leiden; Boston: Brill.

Weiß, Josef. 1910. "Die Arabische Nationalgrammatik Und Die Lateiner." Zeitschrift der Deutschen Morgenländischen Gesellschaft 64 (2): 349-9o. 